\title{
Towards Green Governance-GIS Based Decision Support System for Kodikulam Village, Madurai East, Tamilnadu
}

\author{
V. Padmavathy \\ The American College, Madurai, India \\ T.S.K. Durgesh Nandhini \\ Lady Doak College, Madurai, India \\ R.D.Vijayalakshmi \\ Thiyagarajar College, Madurai, India
}

\begin{abstract}
Estimation of area under bioresources (except agriculture) and its spatial distribution are vital for planning and decision making by the government to promote and develop cashless and green economy sector.The present village level study shows the importance of Decision support system (DSS) in natural resources management and effectiveness of Arc GIS in mapping the bioresources at micro scale. GIS (geographical information system) based overlay analysis indicated that $29.5 \%$ of area under the village is used effectively, $13.7 \%$ area are identified as untouched region and $56.8 \%$ is occupied by other external sources. Occupations other than Agriculture are around 12, has gained prime importance in the local community's livelihoods. This study tries to figure out a prototype of DSS for the potential usage of Bioresources with the help of GIS and its techniques. It is expected that this study will help both the local community and the Government in understanding their strength and weaknesses in utilization of bioresources and Decision making.
\end{abstract}

Keywords: local bioresources, DSS, GIS, remote sensing, livelihoods, Community living

\section{INTRODUCTION}

Reliable and estimation of the bioresources statistics is paramount important for village under state government for taking appropriate policy decisions regarding the management of them. As sample survey and random survey methods alone cannot be considered for decision making, spatial data has an important role in planning and management. Every village has its own uniqueness in its way of livelihood. People constituted in it are, Indigenous and traditional knowledge using people with a historical endurance of resource use practices who often possess a broad knowledge base of the behavior of complex ecological systems in their own localities (Madhav Gadgil et al 1993).Kodikulam was that kind of village with distinct pattern of bioresources and is known to be with characters of smart village.

As remote sensing and GIS provide a flexible environment and acts as a powerful tool for transforming the primary data into secondary form such as maps and figures.(DavideGeneletti 2004)

Feasibility of mapping bioresources area distribution using remote sensing technique has been reported earlierin case of biological diversity of Kerala, a survey conducted at Kalliaseripanchayat, Kannur district (Madhvagadgil et al 1991).Kallissery is the first panchayat in the State where Resource Mapping Programme was completed by CESS in 1991.

There was a socio economic survey following PRM. Panchayat is implementing most of the plans emerged in the process of PRM. Integrated Rural Technology Centre (IRTC) made full use of PRM data and prepared a total development programme for KallisserryPanchayat with necessary support from CESS and Centre for Development Studies. But no attempts were made for integrated management of bioresources along with GIS that would help the administrators, stakeholders and planners to make an ideal Decision Support System.

Bioresources being utilized for various purposes and since they have a particular landscape, we need timely and exact statistics on the areas and regular monitoring and also to take necessary measures in 
the interest of maintaining richness in biodiversity.Both images from satellites and also the ground trothing in obtaining trustable estimation could eventually pave way for GIS based Decision support system for a panchayat through which conservation and management of bioresources can be made

\section{STUdy AREA}

Kodikulam village is present $139 \mathrm{~m}$ above from the sea level and 13 kilometers from the district headquarters of Madurai. Physiography of the study area is present amidst Yaanaimalai hills with good bioresources. Water resources are through ponds and also by the periyar channel. TNAU is one of the landmark of the village. Annual rainfall ranges from $200 \mathrm{~mm}-900 \mathrm{~mm}$ with an average of 500 mm. Soil is mostly Alluvial and red. Paddy, Maize, Millets, Gram varieties, Sugarcane, Banana, Groundnut are the most preferred crops.Total area of the village is 42 acres(Approximately)The total population of the village is 750 (Males:364,Females 386).

\section{Methodology}

A total of 50 households were interviewed and the sample population size is 5.Average respondents were 40 years(range from 15-80 years).Average income of a person at Kodikulam village is 875 $\mathrm{USD}\left(1 \mathrm{USD}=67\right.$ rupees as on May $\left.1^{\mathrm{ST}} 2016\right)$

\section{Primary Data Collection}

Study was carried out through combination of field surveys and community participation. Primary data was collected by trust building, interviews using questionnaires and discussions with the local community. User groups were determined after primary data collection (User group can be defined as group of local community using particular land scape).The following table --- describes the factors used for determining the user groups.

\section{Factors determining user groups}

\begin{tabular}{|l|l|}
\hline s.no & Factors determining the user groups \\
\hline 1. & Availability and accessibility of biodiversity elements. \\
2. & The knowledge and skill required using the biodiversity elements. \\
3. & Gender bias/ age/ health status. \\
4. & Local work calendar. \\
5. & Working attitude of the local people. \\
\hline
\end{tabular}

\section{Secondary Data Collection}

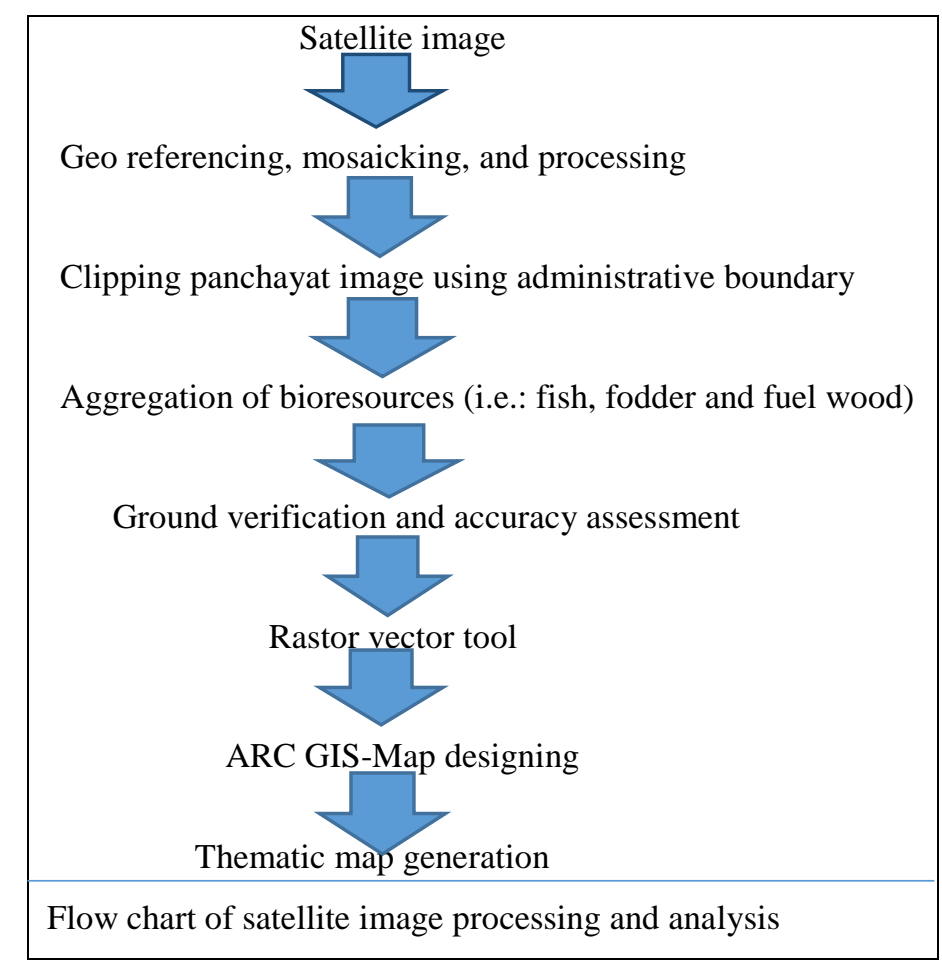


Towards Green Governance-GIS Based Decision Support System for Kodikulam Village, Madurai East, Tamilnadu

Administrative boundary was digitized from toposheet scale 1:2, 50,000 covering study area. Satellite maps and GPS readings were collected from Madurai Kamaraj University. The satellite scenes were mosaic and was clipped using the panchayat boundary. Bitmaps and google earth were super imposed

Using raster to vector conversion tool, village wise bioresources were extracted and using ARCGIS and image processor landscapes and its distribution were made into thematic maps

Relative richness, dominance, fragmentation, patchiness, patch density of each resources was marked in accordance to time, space, conditions and occurrence.

\section{RESUltS AND Discussions}

This study is a field based study, conducted between November 2015 and April 2016. Twenty one field visits were conducted. An average of four hours was used for each visit, hence approximately 160 man-hours were used to meet the local community representatives (men, women youth and children).The following table explains the different sources of household incomes in the village.

\section{SOURCES OF HOUSEHOLd INCOME}

\begin{tabular}{|l|l|l|}
\hline User groups & $\begin{array}{l}\text { Average percentage of } \\
\text { community involvement }\end{array}$ & Average income(per month) \\
\hline Agriculture & $\mathbf{8 0 \%}$ & Rs.6000 \\
\hline Fishing community & $\mathbf{8 5 \%}$ & Rs.12,000 \\
\hline Manure preparing community & $\mathbf{4 5 \%}$ & Rs.500 \\
\hline Hunters and gatherers & $\mathbf{1 5 \%}$ & Rs.3000 \\
\hline Wild fruits collectors & $\mathbf{4 3 \%}$ & Rs.2500 \\
\hline Fuel wood gatherers & $\mathbf{7 6 \%}$ & Rs.500 \\
\hline Foraging community & $\mathbf{4 5 \%}$ & Rs.100 \\
\hline Carpenter community & $\mathbf{2 \%}$ & Rs.25,000 \\
\hline Honey Collectors & $\mathbf{3 4 \%}$ & Rs.2666 \\
\hline $\begin{array}{l}\text { Edible } \\
\text { collectors(insignificant) }\end{array}$ & $\mathbf{0 . 7 5 \%}$ & - \\
\hline Medicinal plants collectors & $\mathbf{5 5 \%}$ & Rs.5000 \\
\hline Cockfight promoters & $\mathbf{3 \%}$ & Varies with betting \\
\hline Tamarind tree Contractors & $\mathbf{6 2 \%}$ & Rs.6000 \\
\hline
\end{tabular}

Table obtained from Padmavathy et al (2017)

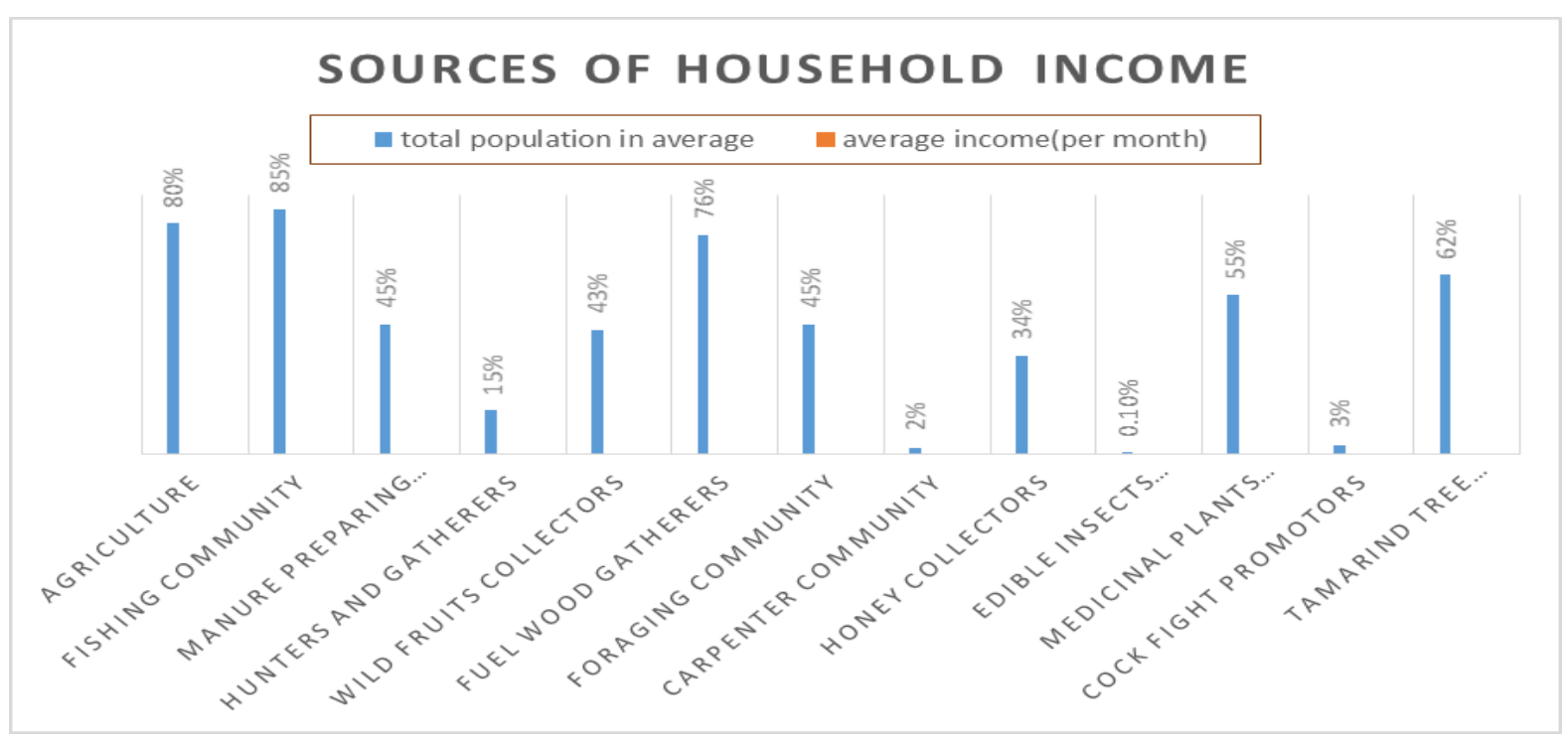

Fig 2: graph on sources of household income at Kodikulam village

Graph obtained from padmavathy et al (2017) 
While analyzing the primary data it was understood that a group dynamics leads many groups working together with the harmony since time immemorial. We have identified user groups who have common interest to particular landscape and those were described in the table above. Similarly table below explains the landscape and common interest of local community on it.

\begin{tabular}{|c|c|c|c|c|}
\hline $\begin{array}{l}\text { S. } \\
\text { no }\end{array}$ & Landscape & $\begin{array}{l}\text { Area (in } \\
\text { Hectares) }\end{array}$ & $\begin{array}{l}\text { Available Local } \\
\text { Resources }\end{array}$ & User Groups Preference \\
\hline 1. & $\begin{array}{l}\text { Agricultural } \\
\text { Land }\end{array}$ & 48.69 & $\begin{array}{l}\text { Medicinal plants } \\
\text { Fodder } \\
\text { Mushrooms }\end{array}$ & $\begin{array}{l}\text { - Farmers (landlords) } \\
\text { - Agricultural laborers } \\
\text { (landless laborers) } \\
\text { - Mushroom Gathers }\end{array}$ \\
\hline 2. & $\begin{array}{l}\text { Settlement } \\
\text { area }\end{array}$ & 9.36 & $\begin{array}{l}\text { Tamarind trees } \\
\text { Livestock }\end{array}$ & $\begin{array}{l}\text { - } \text { Cockfight Promoters(Local Breed) } \\
\text { - Non Wood Product Contractors } \\
\text { - Compost and Manure Producers } \\
\text { - Small scale gardeners } \\
\text { - Medicinal Plant Traders }\end{array}$ \\
\hline 3. & Fallow land & 42.5 & $\begin{array}{l}\text { Palm trees } \\
\text { Fodder } \\
\text { Fuel wood trees } \\
\text { Insects } \\
\text { Medicinal plants }\end{array}$ & $\begin{array}{ll}\text { - } & \text { Palm Craftsmen } \\
\text { - } & \text { Fodder Cultivators } \\
\text { - } & \text { Fuel Wood gatherers } \\
\text { - } & \text { Medicinal Plants collectors } \\
\text { - } & \text { Insect Gathers (Food and Feed) }\end{array}$ \\
\hline 4. & $\begin{array}{l}\text { Mountain } \\
\text { area }\end{array}$ & 8.46 & $\begin{array}{l}\text { Medicinal plants } \\
\text { Honey combs } \\
\text { Small birds and } \\
\text { animals } \\
\text { Wild fruits }\end{array}$ & $\begin{array}{ll}\text { - } & \text { Medicinal Plants / Wild fruit } \\
& \text { Collectors } \\
\text { - } & \text { Honey Gathers } \\
\text { - } & \text { Hunters } \\
\text { - } & \text { (Game Animals) }\end{array}$ \\
\hline 5. & Pond & 5.94 & $\begin{array}{l}\text { Fishes } \\
\text { Mushrooms } \\
\text { Insects }\end{array}$ & $\begin{array}{ll}\text { - } & \text { Fishing community } \\
\text { - } & \text { Mushroom Gathers } \\
\text { - } & \text { Insect Gathers (Food and Feed) }\end{array}$ \\
\hline 6. & Woods & 8.71 & $\begin{array}{l}\text { Palm trees } \\
\text { Fodder } \\
\text { Fuel wood trees } \\
\text { Insects } \\
\text { Medicinal plants } \\
\text { Small birds and } \\
\text { animals } \\
\text { Wild fruits }\end{array}$ & $\begin{array}{ll}\text { - } & \text { Fuel Wood gatherers } \\
\text { - } & \text { Fodder Cultivators } \\
\text { - } & \text { Carpenters } \\
\text { - } & \text { Palm Craftsmen } \\
\text { - } & \text { Hunters(Game Animals) } \\
\text { - } & \text { Insect Gathers (Food and Feed) } \\
\text { - } & \text { Medicinal Plants / Wild fruit } \\
& \text { Collectors }\end{array}$ \\
\hline
\end{tabular}

Table obtained from the work of Padmavathy et al ( 2017 )

On analyzing the calendar of events, each user group is having a unique calendar. It is found that every user group has work at a respective landscape element only for few months. Rest of the time they share their work with other user groups. They have no conflict of interest while sharing their work, they have developed customary laws to farm and utilize biological resources that are available. It helps them to use all the landscape elements and share the local bioresources. If a user group finds a resource in a particular landscape they enjoy the rights of using that resource only for a short duration, the access rights is unwritten and they have managed these resources from time immemorial. Later, they move from the landscape and permit other user groups to find resources which may be useful for them. Adjustment and Conflict management practices are very common among the user groups. In this study livelihood strategies analysis of all the user groups was done. The user groups activity involved in agriculture and bioresource were identified. Different kinds of adaptations and strategies in the presence and absence of rain and the periyar channel is noted GIS mapping software was used to and map the activities of the local community over time and space. 


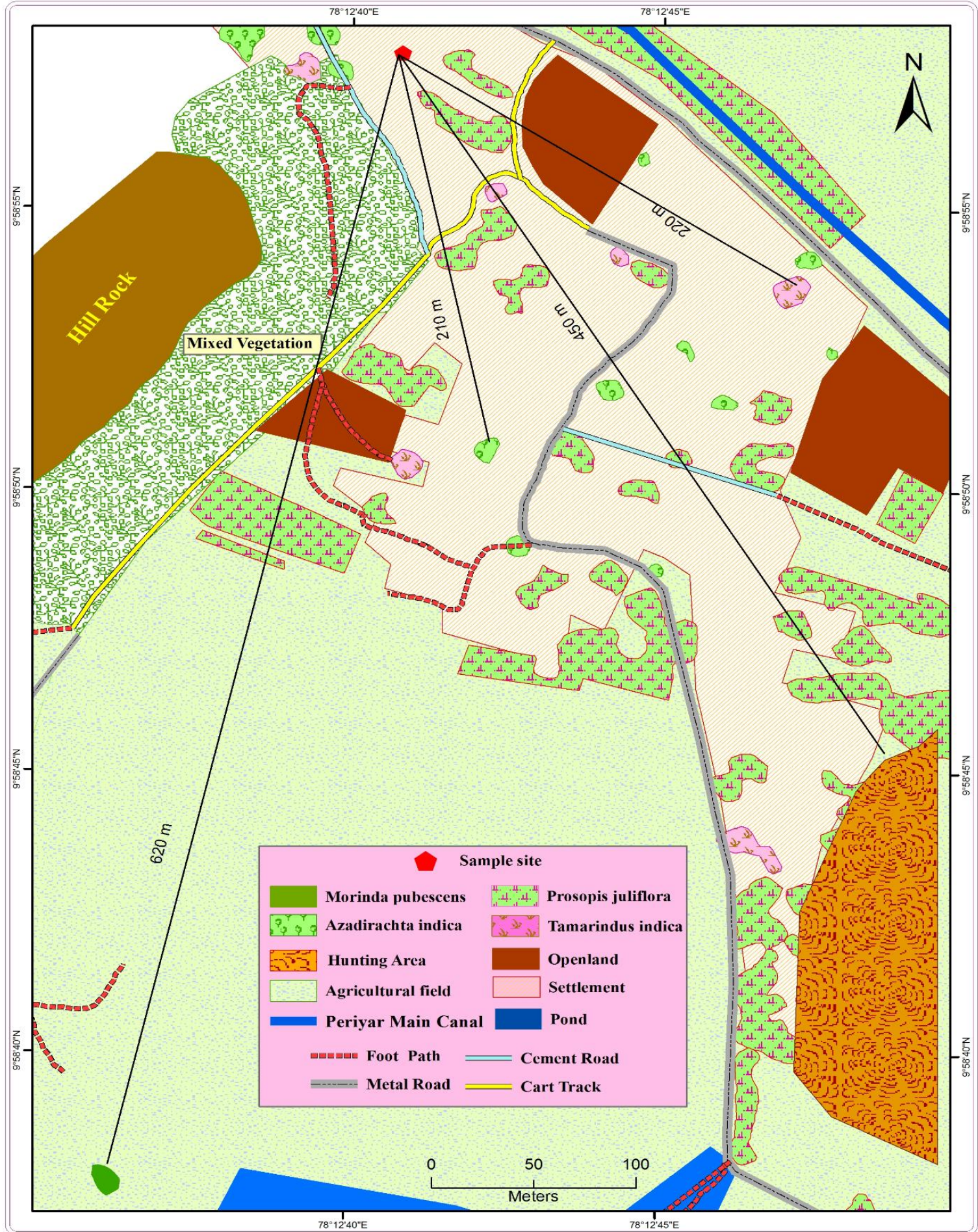

\section{Conclusion}

If we take into account the area all over country the resources and our population we will find that 265 persons have to share the resources available in one sq.km of earth's crust as against 2 persons per sq.km in Australia, 13 persons in the former U.S.S.R and 27 persons in U.S.A and even in china it is 118 persons(Ratnesh., 2006)

Mapping the bioresources of Kodikulam panchayat, Madurai using remote sensing and GIS showed the effective method help preparing a DSS in favor of all the communities. Additional advantage is that satellite based spatial distribution can be integrated with any primary and spatial data. Panchayat board has to plan and formulate policy guidelines and research programs for improving, Maintaining, Managing and conserving the bioresources. 


\section{Padmavathy et al.}

As Research by agricultural economists on natural resources has been distinguished by an interdisciplinary emphasis and a dynamic perspective it is also recognized technological and institutional constraints, has been oriented toward solving concrete resource management and policy problems and has emphasized empirical and quantitative analysis (Erik Lichtenberg et al 2010).This work has attempted to understand a community livelihood from ecological, economic spatial perception.

\section{REFERENCES}

[1] DavideGeneletti 2004 A GIS-based decision support system to identify nature conservation Land Use Policy 21 (2004) 149-160

[2] Erik Lichtenberg, James Shortle, Jameswilen, and David Zilberman 2010 Natural resource economics and conservation: contributions of agricultural economics and agricultural economists Amer. J. Agr. Econ. 92(2): 469-486; doi: 10.1093/ajae/aaq006

[3] Madhav Gadgil, FikretBerkes, Carl Folke 1993 Indigenous Knowledge for Biodiversity Conservation Ambio, Vol. 22, No. 2/3, Biodiversity: Ecology, Economics, Policy (May, 1993), pp.151-156

[4] Madhav GadgilRamachandraGuha 1991 Development of environmental communication in kerala through non-governmental / voluntary and government agencies (ChapterIVshodhganga.inflibnet.ac.in/bitstream/10603/503/11/11_chapter4.pdf)

[5] Padmavathy.V, WinfredThomas.D, Chandramohan.M 2017 Indigenous knowledge on bio resources management for livelihood of the people of Kodikulam village, Madurai east, Tamilnadu, India International journal of Engineering and Technology

[6] Ratnesh Kumar 2006 Environmental Economics Deep \& Deep Publications ISBN-10: 8176297763 ISBN-13: 978-8176297769 